\title{
Pengembangan Perangkat Pembelajaran Fisika Problem Based Learning Melalui Kegiatan Fieldtrip pada Materi Energi
}

\author{
Hatta Yarid $^{1}$ *, Ariswan ${ }^{2}$ \\ ${ }^{1}$ SMA Internasional Budi Mulia. Jalan Raya Tajem Panjen, Wedomartani, Sleman, Indonesia. \\ ${ }^{2}$ Jurusan Pendidikan Fisika, Universitas Negeri Yogyakarta. Jalan Colombo No. 1, Karangmalang, \\ Yogyakarta 55281, Indonesia. \\ * Korespondensi Penulis. Email: yarid_0730@yahoo.co.id
}

\begin{abstract}
Abstrak
Penelitian inibertujuan untuk: (1) menghasilkan perangkat pembelajaran fisika model problem based learning melalui kegiatan fieldtrip yang layak, (2) mengidentifikasi hasil belajar fisika berupa aspek kognitif, minat belajar, dan berpikir kreatif. Jenis penelitian adalah penelitian pengembangan (Research and Development). Validasi dilakukan oleh dua dosen ahli dan uji keterbacaan diujicobakan pada peserta didik. Subjek coba dilakukan pada kelas XI SMA sebanyak 30 peserta didik. Instrumen pengumpulan data menggunakan pedoman wawancara, angket, dan observasi. Analisis data dilakukan dengan analisis isi dan analisis deskriptif presentase. Kesimpulan penelitian adalah: (1) perangkat pembelajaran fisika dinyatakan layak dengan kriteria baik, (2) hasil belajar pada aspek kognitif diperoleh rata-rata kelas eksperimen sebesar 62,93, dan rata-rata kelas kontrol sebesar 57,20. Hasil minat belajar peserta didik, pada kelas eksperimen memiliki rata-rata sebesar 67,50, dan pada kelas kontrol memiliki rata-rata sebesar 65,65. Sedangkan hasil belajar berpikir kreatif peserta didik diperoleh rata-rata kelas eksperimen sebesar 74,91, dan rata-rata kelas kontrol sebesar 65,56.
\end{abstract}

Kata Kunci: model problem based learning, fieldtrip, hasil belajar, kognitif, minat belajar, berpikir kreatif, perangkat pembelajaran fisika.

\section{A Problem Based Learning Model in Physics Learning Equipment Development Through a Fieldtrip Activity in Energy Material}

\begin{abstract}
This research was aimed to: (1) yield a learning-based problem model of physics learning equipment through a feasible fieldtrip, (2) identify physics learning results in the forms of cognitive aspect, learning interest and learner creative thinking from physics learning implementation with a problem-based learning model through a fieldtrip activity.This was a research and development research. The validation towards learning equipment was conducted by two expert lecturers and learning equipment readable was experimented to the learners. The experimented subject was conducted in XI Senior High School grade numbered 30 learners. Data gathering instrument used interview guide, questionnaire and observation. Data analysis was conducted by a content analysis and percentage descriptive analysis.It could be concluded that: (1) physics learning equipment was declared feasible with good criteria, (2) learning results in cognitive aspect in the experimental class obtained average of 62.93 and controlled class average of 57.20. The results of learners learning interest in the experimental class had an average of 67.50 and controlled class average was 65.56. While learning result of learner creative thinking was obtained experimental class average of 74.91 and controlled class average of 65.56.
\end{abstract}

Keywords: problem-based learning model, fieldtrip, learning results, cognitive, learning interest, creative thinking, physics learning equipment

How to Cite: Yarid, H., \& Ariswan, A. (2016). Pengembangan perangkat pembelajaran fisika problem based learning melalui kegiatan fieldtrip pada materi energi. Jurnal Inovasi Pendidikan IPA, 2(1), 24-34. doi:http://dx.doi.org/10.21831/jipi.v2i1.8374

Permalink/DOI: http://dx.doi.org/10.21831/jipi.v2i1.8374 


\section{PENDAHULUAN}

Laporan dari organisasi PISA (Program for International Student Assessment) yang melakukan survey tiga tahunan di berbagai negara terkait kemampuan matematika, kemampuan membaca, dan kemampuan IPA pada siswa yang berusia 15 tahun, hasilnya pada tahun 2012 dari 65 negera yang disurvey, Indonesia menempati urutan ke-64 pada kemampuan IPA.

Beberapa poin yang menjadi dasar acuan penilaian PISA pada kemampuan IPA adalah kemampuan siswa dalam mengidentifikasi masalah dan menjelaskan fenomena alam yang terjadi di lingkungan sekitar. Hal ini sejalan dengan permasalahan yang terjadi pada pembelajaran fisika, yakni masih banyak sumber atau media belajar dan model pembelajaran yang kurang dikembangkan sehingga pembelajaran di kelas kurang menarik dan belum mampu memaksimalkan berpikir kritis peserta didik, seperti pembelajaran yang masih tetap fokus pada teacher center, kecenderungan guru untuk tetap menggunakan metode ceramah tanpa mengkolaborasi dengan metode lain dalam penyampaian materi di kelas, sehingga hal ini mungkin saja mempengaruhi kemampuan peserta didik dalam mengindentifikasi masalah dan menjelaskan fenomena alam pada materi yang disampaikan.

Menurut Kementrian Pendidikan Nasional (Panduan Pengembangan Pembelajaran IPA Secara Terpadu, 2011, p. 1) dikatakan bahwa Pembelajaran IPA berkaitan dengan upaya memahami berbagai fenomena alam secara sistematis. Ilmu Pengetahuan Alam memiliki dimensi sikap ilmiah (scientific attitude), proses ilmiah (scientific process), dan produk ilmiah (scientific product), berupa pengetahuan. Oleh karenanya pembelajaran IPA tidak hanya sekedar mengumpulkan pengetahuan, tetapi harus melatihkan berbagai keterampilan proses, dan menumbuhkan sikap ilmiah.

Masih banyak orang beranggapan bahwa sumber pembelajaran fisika selalu terkait dengan teknologi tinggi, elektronika, digital, dan biaya mahal. Namun sesungguhnya hal tersebut merupakan pemikiran yang sempit dalam memaknai arti dari sebuah sumber belajar. Sumber pembelajaran terdiri atas berbagai macam jenis, dari sumber pembelajaran yang sederhana dan murah hingga canggih dan mahal. Dari mulai rakitan pabrik hingga buatan tangan para guru itu sendiri, bahkan ada pula yang telah disedia-kan oleh alam di lingkungan sekitar kita yang dapat langsung digunakan sebagai sumber belajar.

Dalam kegiatan pembelajaran terdapat dua hal yang turut menentukan berhasil tidaknya suatu proses belajar-mengajar, yaitu pengaturan kelas dan pengajaran itu sendiri (Semiawan, 1989, p. 63). Maksud dari pengajaran itu sendiri adalah guru harus menentukan bagimana cara atau model belajar yang digunakan yang sesuai dengan kondisi kelas. Pengaturan kelas dapat dilakukan dengan membuat pedoman pembelajaran, beberapa diantaranya adalah membuat silabus, RPP, dan lembar kerja peserta didik. Selanjutnya yang dapat dilakukan oleh guru adalah bagaimana perangkat pembelajaran yang dibuat tersebut menyesuaikan dengan model pembelajaran yang telah ditentukan.

Dalam penelitian yang dilakukan oleh beberapa ahli, salah satu model pembelajaran yang mampu mengembangkan peserta didik berpikir ilmiah adalah PBL (problem based learning). Czabanowska (2012), mengatakan bahwa pembelajaran PBL mampu mengembangkan pemikiran peserta didik melalui integrasi informasi, berpikir kritis dan evaluasi diri, serta mengajarkan diri bersikap tanggung jawab dan keterampilan manajemen tim. Sedangkan Hillman (2003) mengatakan bahwa PBL membantu untuk memahami konsep dan implikasinya dalam sistem tersier ke tingkat yang jauh lebih besar.

Tan (2004) menyebutkan bahwa PBL telah diakui sebagai suatu pengembangan dari pembelajaran aktif dan pendekatan pembelajaran yang berpusat pada peserta didik, yang menggunakan masalah-masalah yang tidak terstruktur (masalah-masalah dunia nyata atau masalahmasalah simulasi yang kompleks) sebagai titik awal dan jangkar atau sauh untuk proses pembelajaran.

Kampen (2004) membahas bagaimana manfaat besar dari PBL, khususnya sangat efektif untuk diajarkan kepada peserta didik yang memiliki kemampuan beraneka ragam dan mampu meningkatkan motivasi peserta didik. Chanlin (2008) mengungkapkan bahwa dengan pendekatan PBL, peserta didik yang belajar mandiri dan terlibat aktif pada pengarahan diri, penalaran profesional, dan penentuan nasib sendiri di kelas untuk kegiatan interaktif berbasis web memberikan kontribusi untuk sukses prestasi belajar.. Lebih lanjut oleh Macklin (2008), hasil penelitian menunjukkan bahwa pembelajaran PBL pada kelas ICT dapat berjalan dengan baik ketika diberikan umpan balik 
formatif, karena didukung sikap berpikir kritis mereka tentang proses pencarian informasi. Eldy \& Sulaiman (2013), hasil penelitiannya menunjukkan bahwa perkembangan positif dalam gaya berpikir peserta didik sebelum dan setelah implementasi dengan model PBL.

Celik (2011), saat menyelidiki efek dari pembelajaran berbasis masalah. Pada akhir studi diketahui bahwa ada perbedaan yang signifikan antara dua kelompok dalam proses pembelajaran fisika, pada proses pembelajaran dengan PBL diketahui lebih afektif pada prestasi fisika. Selain itu Sugiarto (2015) mengatakan bahwa PBL membantu meningkatkan kreativitas peserta didik dalam menyelesaikan persoalan lingkungan.

Labra (2012), pembelajaran PBL mampu meningkatkan kelulusan sebesar $60 \%$ pada kelompok eksperimen, terjadi peningkatan hasil akademik dan prestasi belajar peserta didik, menghasilkan peningkatan yang signifikan dalam pembelajaran konseptual, peningkatan yang signifikan dalam kemampuan untuk memecahkan masalah dan dalam sikap dan minat peserta didik terhadap fisika. Selain itu, Selçuk (2010) mengatakan bahwa metode pembelajaran berbasis masalah tidak hanya mendorong pendekatan yang mendalam peserta didik untuk belajar, tetapi juga meningkatkan komponen sikap terhadap fisika. Hasil penelitian juga mengisyaratkan bahwa instruksi fisika PBL berdampak prestasi pada fisika.

Namun berbeda dengan hasil penelitian yang diungkapkan oleh Sahin \& Yorek (2009), secara keseluruhan, hasil penelitian menunjukkan bahwa pendekatan PBL tidak memiliki pengaruh positif terhadap prestasi peserta didik tentang fisika dan belajar fisika. Begitu juga dengan hasil penelitian Gould (2015), yang mengatakan bahwa motivasi belajar peserta didik tidak mempengaruhi perubahan konten pengatahuan di pembelajaran PBL.

Dalam sintaks PBL terdapat aktivitas yang mengharuskan peserta didik melakukan pengamatan dan pengumpul data, sehingga perlu menerapkan metode pembelajaran yang memfasilitasi aktivitas tersebut. Dalam proses tersebut memerlukan sumber belajar yang tepat sehingga dapat berjalan dengan baik. Behrendt \& Franklin (2014), pengalaman belajar di tempat fieldtrip formal dan informal meningkatkan minat siswa, pengetahuan, dan motivasi. Sehingga selain menumbuhkan sikap ilmiah, PBL yang dilakukan dengan aktivitas di luar sekolah dapat meningkatkan minat, pengetahuan dan motivasi peserta didik. Hal ini jelas sesuai dengan konsep dasar tujuan pembelajaran fisika, yakni berpikir ilmiah.

Dalam pembelajaran, fieldtrip dijadikan sebagai sumber belajar karena jumlah sumber belajar yang tersedia di lingkungan ini tidaklah terbatas, sekalipun pada umumnya tidak dirancang secara sengaja untuk kepentingan pendidikan. Sumber belajar lingkungan ini akan semakin memperkaya wawasan dan pengetahuan peserta didik karena mereka belajar tidak terbatas oleh empat dinding kelas, Selain itu kebenarannya lebih akurat, sebab peserta didik dapat mengalami secara langsung dan dapat mengoptimalkan potensi panca inderanya untuk berkomunikasi dengan lingkungan tersebut.

Antwi \& Oppong (2014), Fieldtrip merupakan metode interaktif dan menarik pembelajaran di lingkungan luar. Kegiatan fieldtrip membantu peserta didik untuk berpartisipasi aktif dalam pelajaran sains, selain itu minat peserta didik dalam pembelajaran sains terangsang juga. Dewitt \& Storksdieck (2008) Belajar kognitif dan afektif dapat terjadi sebagai akibat dari kunjungan kelas untuk keluar sekolah, dan hasil belajar pada dasarnya dipengaruhi oleh struktur fieldtrip. Hal yang berbeda diungkapkan oleh Trumper (2006), bahwa tidak ada pengaruh pengalaman belajar di luar sekolah terhadap minat peserta didik belajar fisika.

Kegiatan belajar akan lebih menarik bagi peserta didik sebab lingkungan menyediakan sumber belajar yang sangat beragam dan banyak pilihan. Namun demikian diperlukan adanya kreativitas dan jiwa inovatif dari para guru dalam menerapkan model pembelajaran yang memanfaatkan lingkungan sebagai sumber belajar. Dalam suatu proses belajar mengajar, dua unsur yang sangat penting adalah metode mengajar dan media pengajaran (Arsyad, 2003, p. 15). Dari penjelasan di atas dapat dikatakan bahwa model pembelajaran dan media dalam proses pembelajaran keduanya tidak dapat dipisahkan karena saling berkaitan.

Pada penelitian pengembangan ini digunakan tiga aspek yang diukur dalam hasil belajar pada pembelajaran fisika, yakni aspek kognitif, minat belajar, berpikir kreatif, aspek kognitif peserta didik.

Bloom (Arikunto, 2013, p. 131) mengatakan terdapat ranah kognitif yang dicapai oleh peserta didik selama proses pembelajaran, diantaranya adalah: mengenal (recognition), pemahaman (comprehension), penerapan atau aplikasi (application), analisis (analysis), sintesis (synthesis), dan evaluasi (evaluation). Sedangkan 
menurut Airasian (2001, p. 68) hasil revisi taksonomi Bloom mencantunkan aspek membuat/menciptkan (create).

Arikuno (2013, p. 4) mengatakan bahwa pembelajaran bukanlah satu-satunya faktor yang menentukan hasil belajar. Pada saat peserta didik diberikan pertanyaan tentang perasaan mereka terhadap aspek-aspek tertentu pada pembelajaran, dalam lingkungan yang terpercaya dimana mereka dapat dihargai kejujurannya, peserta didik dapat menyatakan sikap mereka, ketertarikan, rasa suka, dan respon akan jalanya proses pembelajaran.

Slameto (2013, p.180) mengungkapkan bahwa suatu minat dapat diekspresikan oleh peserta didik melalui hal-hal sebagai berikut: (1) peserta didik menunjukkan sikap lebih menyukai suatu hal daripada hal lainnya, (2) dimanifestasikan melalui partisipasi pada aktivitas dan kegiatan, (3) peserta didik cenderung untuk memberikan perhatian yang lebih besar terhadap subjek Menurut Safari (2005, p.152), indikator minat ada empat, yaitu: (1) perasaan senang; (2) ketertarikan siswa; (3) perhatian siswa; dan (4) keterlibatan siswa.

Dari para ahli dapat ditarik beberapa aspek minat dalam penelitian yang menunjukkan bahwa peserta didik memiliki minat pada pembelajaran fisika adalah: (1) peserta didik memperhatikan dengan seksama, indikatornya adalah peserta didik merespon materi yang disampaikan guru; (2) merasa tertarik pada fisika, indikatornya adalah peserta didik mengikuti dengan sungguh-sungguh di kelas; (3) senang untuk tetap mengikuti pembelajaran, indikatornya adalah peserta didik mengungkapkan perasaan senang terhadap pembelajaran; (4) partisipasi peserta didik, indikatornya adalah peserta didik ikut berpartisipasi aktif dalam kegiatan pembelajaran.

Munandar (2012, p. 59) mengemukakan bahwa penilaian kreativitas diukur meliputi dimensi kognitif (berpikir kreatif), dimensi afektif (sikap dan kepribadian), dan dimensi psikomotor (keterampilan kreatif). Dimensi kognitif dari kreativitas mencakup antara lain, kelancaran, kelenturan, orisinalitas dalam berpikir, dan kemampuan untuk merinci (elaborasi).

Aspek tes berpikir kreatif yang digunakan dalam penelitian ini mengadopsi dari tes Torrance (Munandar, 2012, pp. 65-66), Adapun aspek tes tersebut adalah mengukur proses kreativitas terhadap aktivitas-aktivitas seperti: (1) mengajukan pertanyaan;(2) menerka akibat; (3) menerka akibat-akibat sesuatu kejadian; (4) memperbaiki hasil keluaran; (5) penggunaan yang tidak lazim; dan (6) aktivitas yang diandaikan. Sedangkan salah satu unsur penilaian pada aktivitas berpikir kreatif yang diukur diantaranya: (a) kelancaran, (b) kelenturan (flexibility), dan (c) keaslian ide (originality), disertai dengan desain gambar, mengandung unsur manfaat yang tinggi.

\section{METODE}

\section{Jenis Penelitian}

Penelitian ini merupakan penelitian pengembangan. Pada penelitian yang dikembangkan adalah perangkat pembelajaran fisika model PBL melalui kegiatan fieldtrip untuk kelas XI SMA materi pokok energi. Perangkat pembelajaran yang dikembangkan adalah Silabus, Rencana Pelaksanaan Pembelajaran (RPP), Lembar Kerja Peserta Didik (LKPD), Tes Hasil Belajar berupa Tes Aspek Kognitif, Tes Minat, dan Berpikir Keratif.

\section{Target/Subjek Penelitian}

Dalam pengembangan subjek uji coba ini adalah subjek analisis kebutuhan sebanyak dua kelas, 30 peserta didik; subjek uji keterbacaan sebanyak 30 peserta didik; subjek uji coba dilakukan di SMA pada dua kelas di kelas XI, sebanyak 30 peserta didik. Kelas pertama sebagai kelas eksperimen uji coba produk, dan kelas kedua sebagai kelas kontrol; dan subjek evaluasi terdiri atas dosen ahli pendidikan, dan dosen ahli analisis dan konten.

\section{Prosedur}

Pengembangan digunakan dalam penelitian ini diadopsi dari model rancangan pengembangan dari Borg and Gall (2007, p. 591). Tahapan pengembangan dilakukan melalui beberapa tahapan, yakni: (1)menganalisis produk yang dikembangkan, dilakukan dengan menerapkan pendekatan deskriptif kualitatif, yakni melakukan prapenelitian melalui proses studi literatur, observasi di kelas, dan wawancara; (2) mengembangkan produk awal. Setelah melakukan studi pendahuluan mengenai dasar-dasar teori dan konsep pembelajaran, serta observasi pembelajaran di lapangan, maka disusun perangkat pembelajaran yang didasarkan pada: menganalisis proses pembelajaran, menganalisis karakteristik peserta didik, melakukan identifikasi tujuan pembelajaran, mengembangkan perangkat pembelajaran; mengembangkan model pembelajaran, mengembangkan dan memilih bahan ajar, yakni perangkat pembelajaran yang dikembangakan adalah silabus, rencana pelaksa- 
nan pembelajaran (RPP), Lembar Kerja Peserta Didik (LKPD), dan Tes Hasil Belajar berupa Tes aspek Kognitif, Tes Minat Belajar, dan Tes Berpikir Kreatif; (3) melakukan validasi ahli dan revisi. Tahap ini dilakukan dengan validasi perangkat pembelajaran kepada para ahli yakni berupa validasi silabus, rencana pelaksanaan pembelajaran, lembar kerja peserta didik, dan tes hasil belajar. Tujuan dilkukaan validasi ini adalah untuk mendapatkan masukan, tanggapan, saran, komentar terhadap produk yang dikembangkan untuk selanju tnya dilakukan revisi untuk penyempurnaan kualitas produk; (4) melakukan uji keterbacaan pada peserta didik dan revisi. Tahap ini dilakukan dengan menguji coba tes hasil belajar pada peserta didik. Hasil validasi dijadikan dasar untuk mengevaluasi dan merevesi draf awal perangkat pembelajaran sebelum diujicobakan.

Tahap terakhir adalah (5) melakukan uji coba lapangan dan produk akhir. Uji coba ini dilakukan kepada peserta didik dengan jalan melakukan postes terhadap tes hasil belajar berupa tes aspek kognitif, tes minat belajar, dan tes berpikir kreatif. Data kuantitatif yang diperoleh kemudian dianalisis guna menyempurnakan produk akhir, selain itu data juga digunakan untuk mengidentifikasi pencapaian hasil belajar pada dua kelas yang berbeda yakni kelompok kelas kontrol dan kelompok kelas eksperimen.

Instrumen yang digunakan dalam penelitian adalah menggunakan pedoman wawancara, angket, lembar obeservasi, dan tes. (uji coba). Instrument ini digunakan untuk mengumpulkan data tentang: analisis kebutuhan; evaluasi dari ahli, penilaian tentang rancangan produk yang akan dibuat; dan penilaian atau tanggapan guru dalam aktivitas guru dan peserta didik selama proses pembelajaran.

\section{Teknik Analisis}

Teknik yang digunakan dalam penelitian ini ada dua bagian, yakni teknik analisis isi dan dan teknik analisis deskriptif presentase. Pengujian kelayakan instrumen menggunakan skala interval dengan persamaan sebagai berikut:

Tabel 1. Konversi Data Kuantitatif ke Kualitatif dengan Skala Lima (Azwar, 2011, p.163)

\begin{tabular}{cc}
\hline Interval & Kategori \\
\hline $\mathrm{X}>\overline{\mathrm{X}}_{\mathrm{i}}+1,5 \mathrm{SB}_{\mathrm{i}}$ & Sangat Baik \\
$\mathrm{X}_{\mathrm{i}}+\mathrm{SB}_{\mathrm{i}}<\mathrm{X} \leq \overline{\mathrm{X}}_{\mathrm{i}}+1,5 \mathrm{SB}_{\mathrm{i}}$ & Baik \\
$\overline{\mathrm{X}}_{\mathrm{i}}-0,5 \mathrm{SB}_{\mathrm{i}}<\mathrm{X} \leq \overline{\mathrm{X}}_{\mathrm{i}}+\mathrm{SB}_{\mathrm{i}}$ & Cukup Baik \\
$\overline{\mathrm{X}}_{\mathrm{i}}-1,5 \mathrm{SB}_{\mathrm{i}}<\mathrm{X} \leq \overline{\mathrm{X}}_{\mathrm{i}}-0,5 \mathrm{SB}_{\mathrm{i}}$ & Kurang Baik \\
$\mathrm{X} \leq \overline{\mathrm{X}}_{\mathrm{i}}-1,5 \mathrm{SB}_{\mathrm{i}}$ & Tidak Baik \\
\hline
\end{tabular}

$\overline{\mathrm{X}}_{\mathrm{i}} \quad=$ rerata skor ideal

$=1 / 2($ skor maksimal ideal + skor minimal ideal)

$\mathrm{SB}_{\mathrm{i}}=$ simpangan baku ideal

$=1 / 6$ (skor maksimal ideal - skor minimal ideal)

$\mathrm{X} \quad=$ total skor aktual

Analisis deskriptif presentasebertujuan untuk mengolah data yang didapat dari hasil uji coba tahap pertama dan tahap kedua selain itu juga untuk mengetahui seberapa besar hasil belajar yang telah dicapai kelas dari tiap indikator yang diberikan.

Pada Analisis deskriptif presentase akan dilihat dua hal yakni: pertama melihat point biserial atau daya beda dengan Quest Master Program. Adapun penentuan point biserial atau daya beda menurut Ebel dan Frisbie (Safari, 2008, p. 61)) adalah sebagai berikut: kategori daya beda soal; 0,00-0,19 (soal ditolak), 0,200,29 (soal diperbaiki), 0,30-0,39 (soal diterima dan diperbaiki), 0,40-1,00 (soal baik).

Kedua dengan melakukan hasil uji reliabilitas. Hasil ini digunakan untuk mengetahui sejauhmana hasil suatu pengukuran dapat dipercaya. Suatu tes dapat dikatakan mempunyai taraf kepercayaan yang tinggi jika tes tersebut dapat memberikan hasil yang tepat. Maka pengertian reliabilitas tes, berhubungan dengan masalah ketepatan hasil tes, seandainya hasilnya berubah-ubah, perubahan yang terjadi dapat dikatakan tidak berarti. Nilai reliabilitas dapat dicari dengan melihat koefisien nilai alpa.

Adapun persamaan yang digunakan dalam pencapaian hasil belajar aspek kognitit peserta didik tiap indikator $(\mathrm{P})$ adalah:

Keterangan:

$$
\mathrm{P}=\frac{\sum \mathrm{x}_{\mathrm{i}}}{\mathrm{N}_{\text {maks }}} \times 100 \%
$$

$\mathrm{P}=$ Pencapaian hasil belajar

$\mathrm{x}_{\mathrm{i}}=$ indikator

$\mathrm{N}_{\text {maks }}=$ jumlah total peserta didik

Data yang dieproleh dari hasil belajar akan diolah menggunakan Excel Program.

\section{HASIL DAN PEMBAHASAN}

Hasil validasi para ahli dapat di lihat pada Tabel 2 yang menjelaskan tentang skor yang diperoleh tiap produk dari para ahli. 
Jurnal Inovasi Pendidikan IPA, 2 (1), 2016 - 29

Hatta Yarid, Ariswan

Tabel 2. Hasil Uji Kelayakan Produk oleh Para Ahli

\begin{tabular}{ccccccc}
\hline \multirow{2}{*}{ Validator } & \multicolumn{5}{c}{ Skor Tiap Produk } \\
\cline { 2 - 7 } & Silabus & RPP & LKPD & Kognitif & Minat & Berpikir Kreatif \\
\hline Ahli 1 & 4,00 & 4,12 & 4,00 & 4,12 & 3,88 & 4,00 \\
Ahli 2 & 4,14 & 4,06 & 4,00 & 3,88 & 3,88 & 4,00 \\
Rata-rata & 4,07 & 4,09 & 4,00 & 4,00 & 3,88 & 4,00 \\
\hline
\end{tabular}

Kesimpulan validasi dari uji kelayakan produk oleh ahli pertama dan kedua adalah sebagai berikut: (1) silabus memperoleh katagori sangat baik; (2) RPP memperoleh katagori sangat baik; (3) LKPD memperoleh katagori sangat baik; dan (4) Tes aspek kognitif memperoleh katagori baik; (5) Tes minat belajar memperoleh katagori baik; dan (6) Tes berpikir kreatif memperoleh katagori baik. Sehingga secara umum perangkat pembelajaran memperoleh katagori baik, dan layak digunakan. Hasil uji keterbacaan perangkat pembelajaran berupa tes aspek kognitif yang dilakukan sebanyak tiga kali pengujian diperoleh butir soal tiap indikator.

Pada pengujian pertama dari 6 soal yang diujikan sebanyak 6 soal dinyatakan layak, pada pengujian kedua dari 8 soal yang diujikan sebanyak 4 soal dinyatakan layak, dan pengujian ketiga dari 10 soal yang diujikan sebanyak 8 soal dinyatakan layak. Adapun hasil reliabilitas yang diperoleh dari 3 kali pengujian, masingmasing adalah: (1) pengujian pertama memiliki reliability of estimate 0,61 ; (2) pengujian kedua memiliki reliability of estimate 0,77 ; (3) pengujian pertama memiliki reliability of estimate 0,83 . Seluruh hasil tes aspek kognitif kemudian dianalisis tiap item soal yang layak untuk digunakan dalam uji coba. Dari hasil analisis diperoleh item soal aspek kognitif sebanyak 10 soal.

Pada produk tes hasil belajar berpikir kreatif tidak dilakukan uji keterbacaan pada peserta diidk. Proses tes berpikir kreatif menggunakan validasi konten, yakni koreksi dari dosen pembimbing dan dua validator yang ditunjuk oleh dosen pembimbing.

Hasil uji keterbacaan tes minat belajar yang dilakukan sebanyak dua kali validasi dari peserta didik. Pada pengujian pertama dari 20 item yang diujikan sebanyak 15 item dinyatakan layak, pada pengujian kedua dari 20 item yang diujikan sebanyak 15 soal dinyatakan layak. Sehingga dari dua kali uji digunakan sebanyak 18 butir soal. Adapun hasil reliabilitas yang diperoleh dari 2 kali pengujian, masing-masing adalah: (1) pengujian pertama memiliki reliability of estimate 0,56 ; (2) pengujian kedua memiliki reliability of estimate 0,71 .

Hasil pengamatan jalannya proses pembelajaran didapatkan bahwa keterlaksanaan aktivitas guru guna menunjang proses pembelajaran sebesar 95,83\%, sedangkan keterlaksanaan aktivitas peserta didik selama proses pembelajaran sebesar 90,52\%. Selengkapanya dapat dilihat pada Tabel 3.

Tabel 3. Persentase Keterlaksanaan Proses Pembelajaran

\begin{tabular}{cccccccc}
\hline \multirow{2}{*}{ Aktivitas } & \multicolumn{6}{c}{$\begin{array}{c}\text { Skor aktivitas yang diamati } \\
\text { pada pertemuan ke- }\end{array}$} & \multirow{2}{*}{$(\boldsymbol{\%})$} \\
\cline { 2 - 7 } & $\mathbf{1}$ & $\mathbf{2}$ & $\mathbf{3}$ & $\mathbf{4}$ & $\mathbf{5}$ & $\mathbf{6}$ & \\
\hline Guru & 16 & 16 & 15 & 15 & 15 & 15 & 95.83 \\
$\begin{array}{c}\text { Peserta } \\
\text { didik }\end{array}$ & 23 & 21 & 15 & 14 & 14 & 18 & 90.52 \\
\hline
\end{tabular}

Berdasarkan hasil uji coba produk tes hasil belajar aspek kognitif tahap pertama yang dilakukan sebanyak tiga kali pengujian diperoleh butir soal tiap indikator. Pada pengujian pertama dari 6 soal yang diujikan sebanyak 6 soal dinyatakan layak, pada pengujian kedua dari 8 soal yang diujikan sebanyak 4 soal dinyatakan layak, dan pengujian ketiga dari 10 soal yang diujikan sebanyak 8 soal dinyatakan layak. Adapun hasil reliabilitas yang diperoleh dari 3 kali pengujian, masing-masing adalah: (1) pengujian pertama memiliki reliability of estimate 0,61 ; (2) pengujian kedua memiliki reliability of estimate 0,77 ; (3) pengujian pertama memiliki reliability of estimate 0,83 .

Pengujian produk tes hasil belajar aspek kognitif diperoleh dari hasil posttest setelah peserta didik mendapat perlakuan. Hasil tes kognitif ini dirinci berdasarkan tiap indikator. Data lengkap hasil belajar aspek kognitif tiap indikator adalah sebagai berikut: 
Tabel 4. Hasil Tes Aspek Kognitif Tiap Indikator

\begin{tabular}{ccc}
\hline \multirow{2}{*}{ Indikator Soal } & \multicolumn{2}{c}{ Ketuntasan Hasil Belajar } \\
\cline { 2 - 3 } & KA $(\boldsymbol{\%})$ & KB $(\boldsymbol{\%})$ \\
\hline 1 & 70,67 & 65,33 \\
2 & 70,67 & 64,00 \\
3 & 72,00 & 62,67 \\
4 & 50,67 & 28,00 \\
5 & 58,67 & 46,67 \\
6 & 70,67 & 72,67 \\
7 & 80,00 & 76,00 \\
8 & 64,00 & 58,67 \\
9 & 54,57 & 45,33 \\
10 & 37,33 & 53,33 \\
\hline
\end{tabular}

Seluruh hasil tes aspek kognitif kemudian dianalisis tiap item soal yang layak untuk digunakan dalam uji coba. Dari hasil analisis diperoleh item soal aspek kognitif sebanyak 10 soal.

Pengujian produk tes hasil belajar aspek kognitif diperoleh dari hasil posttest setelah peserta didik mendapat perlakuan. Hasil tes kognitif ini dirinci berdasarkan tiap indikator.

Data lengkap hasil belajar aspek kognitif tiap indikator adalah sebagai berikut:

Tabel 5. Hasil Tes Aspek Kognitif

\begin{tabular}{ccccc}
\hline Kelas & $\begin{array}{c}\text { Nilai } \\
\text { Terendah }\end{array}$ & $\begin{array}{c}\text { Nilai } \\
\text { Tertinggi }\end{array}$ & Rerata & SD \\
\hline KA & 42,00 & 94,00 & 62,93 & 16,62 \\
\hline KB & 38,00 & 88,00 & 57,20 & 15,00 \\
\hline
\end{tabular}

Keterangan:

KA: kelas Eksperimen problem based learning

KB: kelas Kontrol

SD: standar deviasi

Tabel 5 dapat diketahui bahwa rerata yang didapat pada kelompok KA adalah 62,93, sedangkan untuk kelompok KB adalah 57,20. Nilai tertinggi dan terendah pada kelompok KA adalah 94,00, dan 42,00, sedangkan nilai tertinggi dan terendah pada kelompok KB adalah 88,00 dan 38,00 .

Hasil uji coba tes minat belajar peserta didik diperoleh melalui angket setelah proses pembelajaran selesai pada kelas eksperimen dan kelas kontrol. Selengkapnya dapat dilihat pada Tabel 6 yang mendiskripsikan minat tertinggi, minat terendah, dan besar rata-rata minat tiap kelas.

Tabel 6. Hasil Tes Minat

\begin{tabular}{ccccc}
\hline Kelas & $\begin{array}{c}\text { Tes } \\
\text { Tertinggi }\end{array}$ & $\begin{array}{c}\text { Tes } \\
\text { Terendah }\end{array}$ & Rerata & SD \\
\hline KA & 86,11 & 54,17 & 67,50 & 8,39 \\
KB & 77,78 & 55,56 & 65,65 & 6,67 \\
\hline
\end{tabular}

Tabel 6 dapat diketahui bahwa rerata yang didapat pada kelompok KA adalah 67,50 sedangkan untuk kelompok KB adalah 65,65. Nilai tertinggi dan terendah pada kelompok KA adalah 86,11 dan 54,17, sedangkan Nilai tertinggi dan terendah pada kelompok KB adalah 77,78 dan 55,56.

Tabel 7. Hasil Tes Berpikir Kreatif

\begin{tabular}{lcccc}
\hline Kelas & $\begin{array}{c}\text { Tes } \\
\text { Tertinggi }\end{array}$ & $\begin{array}{c}\text { Tes } \\
\text { Terendah }\end{array}$ & Rerata & SD \\
\hline KA & 88,89 & 48,61 & 74,91 & 9,98 \\
KB & 88,89 & 38,89 & 65,56 & 13,96 \\
\hline
\end{tabular}

Tabel 7 dapat diketahui bahwa rerata yang didapat pada kelompok KA adalah 74,91 sedangkan untuk kelompok KB adalah 65,56. Nilai tertinggi dan terendah pada kelompok KA adalah 88,89 dan 48,61, sedangkan Nilai tertinggi dan terendah pada kelompok KB adalah 88,89 dan 38,89 .

\section{Revisi Produk Tahap Pertama}

Produk hasil pengembangan disusun berdasarkan pada standar proses, standar penilaian, kompetensi inti, dan kompetensi dasar, serta didasarkan pada karakteristik peserta didik. Selanjutnya pada tahap revisi produk tahap pertama dilakukan setelah produk divalidasi oleh dosen ahli dan diuji coba pada peserta didik.

Revisi produk dari dosen ahli diperoleh dengan kuisioner. Pada kuisioner, dosen ahli menyarankan agar pada bagian kompetensi dasar dari silabus supaya dimasukan unsur kompetensi inti. Selain itu perlu dijelaskan penilaian sikap seperti apa yang akan dinilai.

Pada produk RPP yang perlu direvisi adalah sistematika penulisan pada RPP, kejelasan kompetensi inti pada bagian kompetensi dasar, mencantumkan sintaks PBL dalam tiap langkah pembelajaran.

Revisi terhadap produk LKPD dari dosen ahli adalah: (1) perlu ditambah narasi awal untuk mengkondisikan peserta didik pada objek pengamatan yang dilakukan; (2) layout LKPD dibuat menarik; (3) LKPD harus mampu menfasilitasi peserta didik ditiap sintak PBL.

Pada produk tes hasil belajar terdapat beberapa revisi diantaranya: (1) pernyataan negatif angket pada tes minat tidak selalu menggunakan kata negatif; (2) rubrik penilaian kurang tepat karena menggunakan skor, hal ini karena skor untuk kalimat negatif terbalik; dan (3) perlu perbaikan redaksi soal dan keefektifan kalimat yang digunakan pada produk tes aspek kognitif. 


\section{Jurnal Inovasi Pendidikan IPA, 2 (1), 2016 - 31}

Hatta Yarid, Ariswan

\section{Revisi Produk Tahap Kedua}

Revisi produk tahap kedua dilakukan demi kesempurnaan produk yang dikembangkan setelah dilakukan uji coba tahap pertama.Revisi produk tes berpikir kreatif adalah perlu adanya pencantuman sumber dari gambar, maupun redaksi yang diambil. Sedangkan revisi pada tes aspek kognitif adalah: (1) jumlah soal perlu ditambah minimal 10 soal; (2) perlu adanya gambar dalam soal; dan (3) perbaikan pada kunci jawaban.

\section{Kajian Produk Akhir}

Adapaun gambaran pembelajaran dari penggunaan produk akhir yang telah dikembangkan adalah hasil pengamatan diperoleh data ketercapaian pelaksanaan proses pembelajaran dari aktivitas guru sebesar 95,83\%, sedangkan keterlaksanaan aktivitas peserta didik selama proses pembelajaran sebesar 90,52\%. Dalam aktivitas guru dan peserta didik selama proses pembelajaran terdiri atas lima sintak, yakni: (1) mengorientasi peserta didik pada masalah, (2) mengorganisasikan kegiatan pembelajaran, (3) membimbing penyelidikan mandiri, (4) mengembangkan dan mempresentasikan hasil, dan (5) analisis dan evaluasi. Dalam pelaksanaannya, pertama-tama peserta didik dikelompokkan secara merata berdasarkan tingkat kemampuan diri masing-masing peserta didik. Adapun tujuannya adalah peserta didik dapat mendata permasalahan yang ada dan merumuskan topik permasalahan yang dibahas secara detail melalui kegiatan diskusi. Selain itu hal ini penting sebagai upaya melatih peserta didik dalam berbagi pengalaman guna memperluas wawasan. Selama pengamatan memang tidak semua kelompok dapat melakukan diskusi dengan baik, maka kemudian guru melakukan proses bimbingan selama diskusi dengan harapan proses pembelajaran dapat berlangsung dengan lancar.

Secara garis besar dapat disimpulkan bahwa proses pembelajaran dapat berlangsung sesuai dengan yang direncakan dan kendala yang ditemui selama proses pembelajaran adalah: (1) kurangnya minat dari peserta didik selama proses tanya jawab guna menggali lebih detail informasi yang diperoleh, (2) kurangnya pengawasan dari tiap individu selama di lapangan, (3) dari pengamatan dan wawancara dengan peserta didik, terdapat peserta didik yang memilki tipe-tipe visual, kinestetik dan audio, dari hasil wawancara ditemukan peserta didik kurang begitu tertarik dengan pembelajaran dikarenakan bosan dengan aktivitas yang harus dilakukan, kurang begitu senang belajar di tempat yang ramai, dan menginginkan metode atau model belajar seperti ceramah, mengerjakan soal-soal, dan praktikum di laboratorium.

Secara umum peneliti mendapatkan data awal tentang perkembangan hasil belajar dari kelas eksperimen dan kelas kontrol. Pada kelas $\mathrm{X}$ semester 2 saat belum penjurusan, dari ketiga kelas regular masing-masing memiliki rata-rata 7,$44 ; 7,21$; dan 7,52. Sedangkan pada kelas XI semester 1, kelas eksperimen memiliki rata-rata kelas sebesar78,33 dan kelas kontrol memiliki rata-rata kelas sebesar 77,47. berdasarkan Tabel 4, ditemukan perbedan ketuntasan belajar pada kelas eksperimen dan kelas kontrol pada tiap indikator yang diberikan. Pada kelas eksperimen memiliki ketuntasan lebih baik pada indikator soal ke-1, ke-2, ke-3, ke-4, ke-5, ke-7, ke-8, dan ke-9, sedangkan pada kelas kontrol memiliki ketuntasan belajar lebih baik pada indikator ke-6 dan ke-10. Secara akumulasi indikator, ketuntasan hasil belajar kelas eksperimen sebesar 62,93\% dan kelas kontrol sebesar 57,20\%.

Pada hasil aspek kognitif diperoleh ratarata kelas eksperimen sebesar 62,93, dan ratarata kelas kontrol sebesar 57,20. Hasil minat belajar peserta didik, pada kelas eksperimen memiliki rata-rata sebesar 67,50, dan pada kelas kontrol memiliki rata-rata sebesar 65,65. Sedangkan hasil belajar berpikir kreatif peserta didik diperoleh rata-rata kelas eksperimen sebesar 74,91, dan rata-rata kelas kontrol sebesar 65,56 .

Berdasarkan data-data tersebut bahwa produk akhir yang dikembangkan dalam penelitian ini secara garis besar membawa pengaruh pencapaian hasil belajar bagi peserta didik.

\section{Deskripsi Produk Akhir}

Produk akhir, yakni silabus, RPP, LKPD, dan tes hasil belajar dikembangkan berdasarkan standar kompetensi lulusan dan standar isi untuk satuan pendidikan menengah sesuai dengan pola pembelajaran pada setiap tahun ajaran tertentu. Selain itu juga menyesuaikan dengan karakteristik peserta didik

Produk yang dikembangkan ini didasarkan pada prinsip yang ada, yakni: (1) prinsip ilmiah, bahwa isi produk mengandung kebenaran dan dapat dipertanggungjawabankan; (2) relevan, cakupan, kedalaman, tingkat kesukaran dan urutan penyajian materi sesuai dengan perkembangan jaman, perkembangan fisik, intelektual peserta didik, sosial, emosional, dan spiri- 
tual peserta didik; (3) sistematis, komponenkomponen saling berhubungan secara fungsional dalam mencapai kompetensi; (4) memadai, cakupan indikator, materi pokok, pengalaman belajar, sumber belajar, dan sistem penilaian cukup untuk menunjang pencapaian kompetensi dasar; (5) aktual dan kontekstual, cakupan indikator, materi pokok, pengalaman belajar, sumber belajar, dan sistem penilaian memperhatikan perkembangan ilmu, teknologi, dan seni mutakhir dalam kehidupan nyata, dan peristiwa yang terjadi; (6) fleksibel, keseluruhan komponen produk dapat mengakomodasi keragaman peserta didik, pendidik, serta dinamika perubahan yang terjadi di sekolah dan tuntutan masyarakat.

Secara garis besar produk silabus dan RPP tidak meninggalkan kaidah ketentuan yang sudah ada, akan tetapi terdapat beberapa pengembangan dari segi metode, model, sampai pada langkah pembelajaran. Metode dan model pembelajaran yang digunakan menitikberatkan pada peningkatan kemampuan berpikir ilmiah peserta didik. Hal ini dikarenakan proses pembelajaran problem based learning dengan fieldtrip, siswa memang diberi kelugasan dalam menganalisis objek kajian sampai bagaimana kemudian siwa diharuskan menemukan sebuah solusi dari masalah pada objek kajian. Sehingga produk ini secara umum sangat menekankan pada proses pembelajaran.

Pada produk LKPD dan lembar tes hasil belajar berupa berpikir kreatif, pengembangan yang dilakukan adalah terdapat sebuah pernyataan atau deskripsi pada produk yang memberikan gambaran umum secara fakta bahwa siswa ditekankan mencari sebuah solusi dari masalah yang diberikan oleh pendidik. Selain itu pada lembar LKPD dan tes belajar, proses berpikir ilmiah tetap diperhatikan dengan tidak menghilangkan unsur dari sintaks pembelajaran problem based learning, mulai dari merumuskan masalah sampai menemukan solusi dari masalah tersebut.

Produk yang berupa tes minat yang dikembangkan adalah produk ini mengukur aspek tentang perhatian, ketertarikan pada materi, kesenangan pada materi pembelajaran, tingkat respon siswa selama pembelajaran, dan sikap keterbukaan yang ditunjukkan oleh siswa selama proses pembelajaran. Sehingga dari hal tersebut diharapkan pendidik mampu menemukan solusi dari masalah yang dialami oleh peserta didik selama di kelas dari berbagai sudut pandang.

Sedangkan pengembangan pada produk akhir berupa tes hasil belajar adalah terdapat kolaborasi indikator ketercapaian pembelajaran. Artinya peserta didik diharuskan mencari solusi diluar indikator guna menyelesaikan masalah yang diberikan selama proses pembelajaran. Sehingga dalam hal ini peserta didik diajarkan untuk selalu melakukan kegiatan eksplorasi pada sumber belajar.

\section{SIMPULAN DAN SARAN}

\section{Simpulan}

Adapun kesimpulan penelitian adalah: (1) perangkat pembelajaran fisika dinyatakan layak dengan kriteria baik, (2) hasil belajar pada aspek kognitif diperoleh rata-rata kelas eksperimen sebesar 62,93, dan rata-rata kelas kontrol sebesar 57,20 . Hasil minat belajar peserta didik, pada kelas eksperimen memiliki rata-rata sebesar 67,50 , dan pada kelas kontrol memiliki rata-rata sebesar 65,65. Sedangkan hasil belajar berpikir kreatif peserta didik diperoleh rata-rata kelas eksperimen sebesar 74,91, dan rata-rata kelas kontrol sebesar 65,56.

\section{Saran}

Adapun saran dalam penelitian adalah: (1) peneliti lain perlu memperhatikan sinergisitas waktu antara agenda pembelajaran di kelas, agenda program sekolah, dan tempat fieldtrip; (2) sebaiknya ditambahkan aspek lain selain aspek yang sudah diujikan dalam penelitian, misalnya aspek keterampilan proses, sehingga diperoleh gambaran lebih jelas pengaruh model problem based of learning melalui kegiatan fieldtrip terhadap hasil belajar secara keseluruhan.

\section{DAFTAR PUSTAKA}

Antwi, V. \& Oppong, C. Snr. (2014). Using field trip to promote active participation among pupils of mumford community jhs ghana to improve their performance in science. Journal of Education And Curriculum Development Research, 2(4),152-166. http://www.projournals.org/JECDR.

Arikunto, S. (2013). Dasar-dasar evaluasi pendidikan. Jakarta: Bumi Aksara.

Arsyad, A. (2013). Media pembelajaran. Jakarta: Raja Grafindo Persada.

Behrendt, M., \& Franklin, T. (2014) .A review of research on school field trips and their value in education. International Journal of Environmental \& Scienc, 9 (3), 
http://www.ijese.com/ijese.2014.213a.p df.

Borg, W. R; Gall, J. P; Gall, M. D. (2007). Educational research, an introduction, eighth. New York: Longman.

ChanLin, Lih-Juan. (2008). Autonomous learning in a PBL approach. LIBRES: Library \& Information Science Research Electronic Journal., 18, 1-14. http://www.researchgate.net/publication /255609722_Autonomous_Learning_in _a_PBL_Approach.

Celik, P., Onder, F., \& Silay, I. (2011). The effects of problem-based learning on the students' success in physics course.Procedia - Social and Behavioral Sciences, 28, 656 - 660.

Czabanowska, K., Mous, J. H. C., Meijer, A. W. M., \& Back, P. S. (2012). Problembased Learning Revisited, introduction of Active and Self-directed Learning to reduce fatigue among students, Journal of University Teaching \& Learning Practice, $\quad 9 \quad$ (1), 1-13. http://ro.uow.edu.au/jutlp/vol9/iss1/6

Depdiknas. (2011). Panduan pengembangan IPA secara terpadu, Tahun 2011.

Dewitt, J., \& Storksdieck, M. (2008). A short review of school field trips: Key findings from the past and implications for the future, Visitor Studies Association, 11(2), 181-197. http://dx.doi.org/10.1080/106455708023 55562.

Eldy, E. F. \& Sulaiman, F. (2013). The role of PBL in improving physics students' creative thinking and its imprint on gender. International Journal of Education and Research,1(6), 110.http://www.ijern.com/journal/June2013/14.pdf.

Gould, K., Sadera,W. \& McNary, S. (2015). Comparing changes in content knowledge between online problem based learning and traditional instruction in undergraduate health professional students. MERLOT Journal of Online Learning and Teaching, 11(1), $74-$

86.http://jolt.merlot.org/vol11no1/Gould _0315.pdf

Folashade, A., \& Akinbobola, A. O. (2009). Constructivist problem based learning technique and the academic achievement of physics students with low ability level in 20 nigerian secondary schools. Eurasia Journal of Physics and Chemistry Education. 1(1). 45-51.

http://www.eurasianjournals.com/index. php/ejpce/article/view/34.

Hillman, W. (2003). Learning how to learn: problem based learning.. Australian Journal of Teacher Education, 28(2,) 110.http://dx.doi.org/10.14221/ajte.2003v $28 \mathrm{n} 2.1$.

Kampen, V. P., Banahan, C.,Kelly, M., McLoughlin, E., \& O'Leary, E (2004). Teaching a single physics module through problem based learning in alecture-based curriculum. America. Journal Physics, 72(6), 829834.http://dx.doi.org/10.1119/1.1645280

Labra, C. B., Marti, A. G, \& Torregrosa, J. M.(2012). Effects of a problem-based structure of physics contents on conceptual learning and the ability to solve problems. International Journal of Science Education, 117.http://www.tandfonline.com/doi/abs/ 10.1080/09500693.2011.619210\#.VdT9 m6GZJvA.

Macklin, A. S. (2008). A PBL approach for teaching complex information and communication technology (ICT) skills in higher education. Community \& Junior College Libraries, 14, 233-249. http://www.tandfonline.com/doi/abs/10. 1080/02763910802336381?journalCode =wjcl20\#.VdT-laGZJvA.

Mahmudi, A. (2010). Mengukur kemampuan berpikir kreatif matematis. Makalah disajikan pada Konferensi Nasional Matematika XV UNIMA. Manado: Jurusan Pendidikan Matematika UNY.

Munandar, U. (2012). Pengembangan kreativitas anak berbakat. Jakarta: Rineka Cipta.

PISA. (2012). Result in focus what 15-year-old know and what they can do with wahat they know. New York: Programme for Internastional Studet Assement, OECD.

Safari, M. A. (2005). Penulisan butir soal berdasarkan penilaian berbasis kompetensi. Jakarta: APSI Pusat. 
Hatta Yarid, Ariswan

Safari, M. A. (2008). Analisis butir soal: dengan manual, kalkulator, dan komputer. Jakarta: APSI Pusat.

Sahin, M.,\& Yorek, N. (2009). A comparison of problem-based learning and traditional lecture students' expectations and course grades in an introductory physics classroom.Academic Journals Scientific Research and Essay, Vol 4 (8), 753-762. http://www.academicjournals.org/SRE.

Selçuk, G.S. (2010). The effects of problembased learning on pre-service teachers' achievement, approaches and attitudes towards learning physics. International Journal of the Physical Sciences, 5(6), 711-723.

http://boltz.ccne.ufsm.br/pub/mpeac/oth er/selcuk_ijps_vol5_2010.pdf

Semiawan, C., Tangyong, A. F., Belen, S., Matahelemual, Y., \& Suseloardjo, W. (1989). Pendekatan keterampilan proses. Jakarta: PT Gramedia.
Slameto. (2013). Belajar dan faktor-faktor yang mempengaruhinya. Jakarta: PT Rineka Cipta.

Sugiarto, A., \& Djukri, D. (2015). Pembelajaran berbasis SETS sebagai upaya meningkatkan kreativitas dalam pemecahan masalah pencemaran lingkungan. Jurnal Inovasi Pendidikan IPA, $\quad 1(1), \quad 1-11 . \quad$ Retrieved fromhttp://journal.uny.ac.id/index.php/ji pi/article/view/4527

Tan, O. S. (2004). Cognition, metacognition, and problem-based learning, inenhancing thinking through problembased learning approaches. Singapore: Cengag Learning.

Trumper, R. (2006). Factors affecting junior high school students' interest in physics. Journal of Science Education and Technology, 15(1), 47-58. 